\title{
Challenges Faced by Students and Teachers on Writing Skills in ESL Contexts: A Literature Review
}

\author{
Rachel Nyanamoney Moses, Maslawati Mohamad \\ Faculty of Education, Universiti Kebangsaan Malaysia, Bangi, Malaysia \\ Email: rachelmoses85@gmail.com,maslawati@ukm.edu.my
}

How to cite this paper: Moses, R. N., \& Mohamad, M. (2019). Challenges Faced by Students and Teachers on Writing Skills in ESL Contexts: A Literature Review. Creative Education, 10, 3385-3391. https://doi.org/10.4236/ce.2019.1013260

Received: October 7, 2019

Accepted: December 13, 2019

Published: December 16, 2019

Copyright $\odot 2019$ by author(s) and Scientific Research Publishing Inc. This work is licensed under the Creative Commons Attribution International License (CC BY 4.0).

http://creativecommons.org/licenses/by/4.0/

\section{c) (i) Open Access}

\begin{abstract}
English is an international language and in demand today. English is by far the most widely used language around the world. However, English language writing has always been a challenge for second language students to master. Developing students' ability in writing is one of the major challenges faced by the ESL teachers in most schools nowadays. Nevertheless, writing has always been a major difficulty faced by students in English language learning, especially in elementary schools. Not only that, teachers are also facing some challenges in teaching writing skills for students in elementary schools. Thus, this study aims to explore the challenges faced by both the students and teachers in learning as well as teaching writing skills in elementary schools.
\end{abstract}

\section{Keywords}

Writing Skills, Teaching and Learning Writing, Challenges, Elementary School, English as a Second Language

\section{Introduction}

English is used in the world as a lingua franca among people from different cultures, ethnic, and social backgrounds (Dewi, 2015). The ability to teach writing effectively at elementary schools is one of the vital skills among English teachers. Writing is a major component in the teaching of English. The teaching of writing has been conducted as early as in the early years where students start to learn how to form letters correctly.

There are many consequences that could lead to major drawbacks in students' academic performance if they have a weak foundation in writing. Writing is not only vital in order to develop their academic performance, but also contributes 
to their social and emotional development. Moreover, in this competitive world, writing is also one of the skills that is necessary to excel. Their inability to write well, may affect their chances to secure a job in the future. Therefore, this issue needs to be tackled effectively.

However, teaching writing has become difficult because of the challenges faced by the students in learning writing skills. Some of the challenges that are faced by the ESL students are lack of vocabulary, poor grammar, poor spelling, students' readiness and lack of exposure to books and reading materials.

The challenges faced by the students' have made it challenging for teachers to teach writing skills. The challenges that are faced by the teachers to teach writing skills are difficult to motivate their students, students of diverse levels, difficult materials and time constraints to teach the students. In order to improve a student's writing ability, more attention must be given by a teacher to teach writing such as giving guidance and feedback.

Therefore, a teacher needs to be aware of the challenges faced by other English teachers in teaching writing skills and ESL students' challenges in learning to write. This paper provides a literature review on the challenges faced by both teachers as well as students in teaching and learning writing skills.

\section{Literature Review}

Writing is one of the skills among speaking, reading and listening skills in English. Writing is a multiplex activity claimed by Ling (2016). Writing activities need to be conducted among students since elementary school so that the students can generate good pieces of writing in the future. Even though there are many subjects in elementary schools, writing is known as one of the most vital academic subjects for students.

The beating heart of English is "story". A "story" can take any form be it a journalistic article, a research documentary or a fantasy novel. It serves as a method of explaining and passing information intended for a specific objective. Thus, all writing may be taken in a form of story in a larger perspective.

\subsection{Demand on Writing Skills}

Writing is a crucial skill that will benefit the rest of the students' lives. Introducing and practicing writing with attractive activities in schools, could increase students' confidence and they will fall in love with writing in a long run. Immediately, writing skills are vital for lower primary students to continue learning in all academic areas, communication and self-expression.

Writing exercises in schools promote the improvement of penmanship as well as overall academic development through troubleshooting and critical thinking. The writing process also is applicable to other areas such as Mathematics and Sciences, where the learned traits of planning, research and review is applied as well. General knowledge and vocabulary are also improved as a subsequent effect. 
Through journals and personal story writing, students can discover themselves and work through their real-life problems. A report by the U.S. Department of Health and Human Services states that writing can provide a therapeutic outlet to help students cope when they are facing hard time in their life such as having problems with their parents or feeling sad.

Writing assists students with their social development. Writing connects the students to be in tune with what happens in the world around them. Students need to consider the audience and purpose in writing. This will help the students with their verbal communication at the same time. Writing with friends' feedback, makes students to learn among themselves.

As students' progress through their school years, they will need to be both literate and computer literate to succeed. While the two skills complement each other, some computer tools such as spelling and grammar checks, can prevent them from developing their writing skills. As an example, students who are not practicing their handwriting when they are writing with a keyboard. It is also important for the students to know that they need to use their own knowledge, not by replacing their knowledge with computers, because computers can make mistakes too.

Today, due to the evolution of information technology, writers are in demand to create digital media content. A content writer is needed for digital marketing corporations. News websites, social media marketing corporations and other related and non-related IT corporations need writers to help them through writing for digital marketing channels such as brand quotes, advertisement, social media posts, blogs etc.

\subsection{Purpose of Students' Writing by Using Different Writing Strategies}

There are many ways to improve students' penmanship through writing exercises at elementary level. Students may use different writing methods at a time. There are various teaching writing strategies for examples pre-writing, writing warm-up, collaboratively write, using sentence starters, and guided writing. All the teaching of writing strategies cannot be used at the same time as they may have different teaching objectives. Employing various teaching techniques to teach writing will help the students improve their writing skills in English. As the students have interest and become active participants in learning, the learning process will fall on the right track. Besides, using various writing strategies will make the students think creatively. Students may use what they know by combining opinions and facts, thus, making a new piece of writing. According to Bloom's Taxonomy, this is high level ability.

\subsection{Challenges Faced by the Students in Learning Writing Skills}

Each student may face different challenges in learning writing. All the students are special and unique in their own ways. These challenges will somehow pull 
back the students from moving forward to produce a good piece of writing. The following paragraphs are about challenges faced by students in writing.

Lack of vocabulary has caused the students to face challenges in acquiring writing skills claimed Misbah et al. (2017). Vocabulary is the fundamental element in constructing sentences which is the core of effective writing skills Asep (2014). Students almost use spoken and written words every single day to communicate their ideas, beliefs and feelings with people around them. Good vocabulary repertoire can help students to speak or write to deliver their thoughts. Usage of electronic dictionary and more reading activities can help students with limited vocabulary.

Some elementary school students are also having trouble with grammar. Grammar plays an important role in writing. Grammar provides information that helps the readers to understand its meaning. It is a structure that conveys the detailed meaning of the writer to the reader. Grammar also explains the forms and structure of words, called morphology and how they are arranged in sentences, called syntax. By having very limited knowledge in grammar, students will face anxiety to write sentences with correct grammar. According to $\mathrm{Mu}$ hammad Fareed et al. (2016) students make mistakes in subject-verb agreement, pronouns, tenses, articles, prepositions and basic sentence structures. Grammar ability can be improved through reading activity and grammar related activities.

Poor spelling is another cause of anxiety for students in learning writing skill and this is supported by Nyang'au Benard (2014). Having good ability in spelling will lead to positive learning of writing skill. If the students are struggling with spellings, it will hold them back to move forward. The students have the habit to spell according to their pronunciation and this will lead to wrong spelling as mentioned by Afrin (2016). The students will either add or leave letters of the words. For an example "ballon" instead of "balloon." According to Nyang'au Benard (2014) memorization of the spelling will help the students to have good spelling.

Students' readiness is another challenge in learning writing and this was supported by Foster (2015). According to Winarso (2016) in order to complete a task successfully, readiness is very important. The readiness can either be physical readiness and mental preparedness. If this is not occurring, students will be having challenges in writing. Students will not be mentally prepared to learn in the classroom if they are not ready. It is very important for the students to be ready before they enter the classroom. According to Foster (2015) motivating and attracting the students' attention can help students' readiness in learning writing.

Lack of exposure to books and reading materials are other challenges for elementary school students in learning writing and this is supported by Foster (2015). According to Muhammad Fareed et al. (2016) many students find it very challenging to get enough and significant source of information. Lack of extensive reading will not help the students to write good sentences or paragraphs. 
This is because reading and writing are interrelated. If the students are not reading books or other reading materials, they are going to have lack of ideas and vocabulary to write. Their brain neurons will be connected to each other to come out with a good writing if they read more and connecting the ideas with their prior knowledge. Foster (2015) explained that exposure to different reading materials can help the students to be aware with language awareness explained.

Last but not the least, lack of motivation is another challenge faced by the students. If the students are not motivated, they might not be interested to proceed with their learning process. Motivation is important in improving students' learning results claimed Gbollie \& Keamu (2017). Teachers could motivate the students by rewarding them with simple motivational phrases by saying "Good job!", “Good try!”, “Keep it up” etc. Positive reward will make the students go further in their learning process.

\subsection{Challenges Faced by the Teachers in Teaching Writing Skills}

Teaching has always been the challenging part for teachers. Teaching English at primary level is naturally much more different from teaching in other levels of students such as secondary and tertiary levels. The challenge will somehow make the teachers' teaching ineffective. The following are the challenges faced by teachers.

Nowadays, teachers are having a hard time in motivating the students. Not because of the students' naughtiness, but the students are not interested in learning writing and this claim is supported by Asep (2014). The younger generation has the perception that they can do whatever they please since much freedom has been given to them by their parents. When students choose to feel reluctant in learning, it is a sign of lack of motivation (Abrar, 2016).

Having different levels of students in the classroom is another challenge faced by teachers to teach writing. In many elementary classrooms, students from different levels are placed in the same classroom. Different levels of students will result to difficulty to teachers in order to cater all of their levels simultaneously (Asep, 2014). Different levels of writing ability will require the teachers to use different approaches. As a result, the teachers feel difficult to plan their lessons and prepare appropriate activities for the students.

Parental indifference is another challenge. Lack of parents' support will make the teachers having a hard time to help the students. Students who feel lack of warmth and affection from their parents will draw them back from succeeding in their learning process (Gündoğmuş, 2018). This is due to little guidance, motivation and support from their parents.

Besides, lack of professional experience is another challenge faced by the teachers (Gündoğmuş, 2018). Having lack of professional experience will lead to stress and tension to teach at elementary school students especially among novice teachers. The multiple roles of teacher are also a challenge. The teachers' experience is depending on the level of their previous experience and training. It 
will take time for the novice teachers to adapt themselves with their students very well. Teachers can only prepare appropriate activities if they know well about their students' proficiency level, and interests. Not only that, longer time is needed for teachers to prepare new teaching materials, appropriate lesson plans, suitable activities, and provide comments or reflections.

Finally, according to Anyiendah (2017) lack of students' interest is another challenge. Developing writing skills is always challenging, however, it is always an interesting task. Especially when it comes to writing, some students zone out. Students feel lack of interest in writing because they need to know many aspects in order to produce a good piece of work. The students need to know punctuations, grammar, vocabulary, spelling and sentence structure in order to write a good piece of writing.

\section{Conclusion and Implications}

This study is to explore the literature review on the challenges faced by both the students and teachers in learning and teaching writing skills. It can be concluded that school students are facing many challenges to learn writing skills and it is not easy for English teachers to teach them writing skills. The existing literature has identified demands on writing skills in English, purpose of students' writing by using various writing strategies, challenges faced by both the students and teachers in learning and teaching writing skills and past studies on the challenges faced by students and teachers to learn and teach writing skills among ESL school students.

By understanding both the students' and teachers' challenges in learning and teaching writing skills, the teachers could choose the best possible approach to teach writing skills by giving feedback and guidance. Besides, the school management should take necessary actions on the challenges faced by the teachers in order to facilitate the teachers to have effective teaching process. Finally, teachers may stress the importance of learning writing skills to the students in order to motivate them to learn writing skills.

\section{Conflicts of Interest}

The authors declare no conflicts of interest regarding the publication of this paper.

\section{References}

Abrar, M. (2016). Teaching English Problems: An Analysis of EFL Primary School Teachers in Kuala Tungkal. Birmingham, UK: The 16th Indonesian Scholars International Convention.

Afrin, S. (2016). Writing Problems of Non-English Major Undergraduate Students in Bangladesh: An Observation. Open Journal of Social Sciences, 4, 104-115. https://doi.org/10.4236/jss.2016.43016

Anyiendah, M. S. (2017). Challenges Faced by Teachers When Teaching English in Public Primary Schools in Kenya. https://doi.org/10.3389/feduc.2017.00013 
Asep, S. (2014). The Challenges in Teaching Writing Skill at Junior High School: Problems and Solutions.

Dewi, A. (2015). Perception of English: A Study of Staff and Students at Universities in Yogyakarta, Indonesia. Cambridge: Cambridge Scholars Publishing.

Fareed, M., Ashraf, A., \& Bilal, M. (2016). ESL Learners' Writing Skills: Problems, Factors and Suggestions. Journal of Education and Social Sciences, 4, 81-92. https://doi.org/10.20547/jess0421604201

Foster, B. (2015). Teaching Children with Reading and Writing Difficulties in Regular Schools.

Gbollie, C., \& Keamu, H. P. (2017). Student Academic Performance: The Role of Motivation, Strategies, and Perceived Factors Hindering Liberian Junior and Senior High School Students Learning. Education Research International, 2017, Article ID: 1789084. https://doi.org/10.1155/2017/1789084

Gündoğmuş, H. D. (2018). The Difficulties Experienced by Teachers in the Process of Primary Reading and Writing Instruction and Their Solution Offers for Eliminating These Difficulties. Universal Journal of Educational Research, 6, 333-339. https://doi.org/10.13189/ujer.2018.060216

Ling, Y. L. C. (2016). Teaching Writing. In W. A. Renandya, \& H. P. Widodo (Eds.), English Language Teaching Today: Building a Closer Link between Theory and Practice (pp. 1-20). New York: Springer International.

Misbah, N. H., Mohamad, M., Yunus, M., \& Ya'acob, A. (2017). Identifying the Factors Contributing to Students' Difficulties in the English Language Learning. Creative Education, 8, 1999-2008. https://doi.org/10.4236/ce.2017.813136

Nyang'au Benard, N. (2014). Challenges Students Face in Learning Essay Writing Skills in English Language in Secondary Schools in Manga District, Nyamira County, Kenya.

Winarso, W. (2016). Assessing the Readiness of Student Learning Activity and Learning Outcome. Jurnal Pencerahan, 10, 81-94. 